\title{
Combustion synthesis and photoluminescence study of silicate biomaterials
}

\author{
V B BHATKAR* and N V BHATKAR \\ Department of Physics, Shri Shivaji College, Akot 444 101, India
}

MS received 16 March 2010; revised 23 April 2011

\begin{abstract}
Silicate based bioceramics are promising candidates as biomaterials for tissue engineering. The combustion synthesis method provides control on the morphology and particle size of the synthesized material. This paper discusses the combustion synthesis of akermanite $\left(\mathrm{Ca}_{2} \mathrm{MgSi}_{2} \mathrm{O}_{7}\right.$ and $\left.\mathrm{Sr}_{2} \mathrm{MgSi}_{2} \mathrm{O}_{7}\right)$, which has been shown to have good in vitro and in vivo bioactivities by earlier studies. Both $\mathrm{Ca}_{2} \mathrm{MgSi}_{2} \mathrm{O}_{7}$ and $\mathrm{Sr}_{2} \mathrm{MgSi}_{2} \mathrm{O}_{7}$ have akermanite structure. $\mathrm{Ca}_{2} \mathrm{MgSi}_{2} \mathrm{O}_{7}$ and $\mathrm{Sr}_{2} \mathrm{MgSi}_{2} \mathrm{O}_{7}$ were prepared using urea and ammonium nitrate. The combustion synthesis using urea and ammonium nitrate was found to be cost effective and efficient method of synthesis. The photoluminescence study of $\mathrm{Ca}_{2} \mathrm{MgSi}_{2} \mathrm{O}_{7}: \mathrm{Eu}^{2+}$ and $\mathrm{Sr}_{2} \mathrm{MgSi}_{2} \mathrm{O}_{7}: \mathrm{Eu}^{2+}$ shows host specific intense emission of $\mathbf{E u}^{2+}$.
\end{abstract}

Keywords. Biomaterials; silicates; akermanite; combustion synthesis; photoluminescence.

\section{Introduction}

It is essential to develop biocompatible, bioactive, bioresorbable and durable materials for orthopaedic and dental implants, that are capable of bearing high stress and loads, and that invoke positive cellular and genetic responses for the rapid repair, modification, regeneration and maintenance of the affected tissue in human body (Cerruti and Sahai 2006). Silicate-based bioceramics, including silicate bioglass 45S5 (Hench 1991; Radev et al 2009), wollastonite $\left(\mathrm{CaSiO}_{3}\right)$ ( $\mathrm{Liu}$ et al 2004; Wu et al 2007; Xue et al 2007), akermanite $\left(\mathrm{Ca}_{2} \mathrm{MgSi}_{2} \mathrm{O}_{7}\right)$ (Radev et al 2009), diopside $\left(\mathrm{Ca}_{2} \mathrm{MgSi}_{2} \mathrm{O}_{6}\right)$ (Iwata et al 2004; Wu and Chang 2007) and merwinite $\left(\mathrm{Ca}_{3} \mathrm{MgSi}_{2} \mathrm{O}_{8}\right)$ (Ou et al 2008) ceramics have been shown to have excellent apatite forming abilities in simulated body fluids. Other studies showed that these silicate ceramics also possess good in vivo bioactivity (Hench 1998; Nonami and Tsutsumi 1999; Xu et al 2008; Huang et al 2009). In vitro and in vivo investigations of a calcium magnesium silicate $\left(\mathrm{Ca}_{2} \mathrm{MgSi}_{2} \mathrm{O}_{7}\right)$ bioceramic for bone regeneration showed that akermanite extract promoted proliferation and osteogenic differentiation. These results suggest that akermanite might be a potential and attractive bioceramic for tissue engineering (Hongli et al 2006; Wu et al 2006; Liu et al 2008; Yan et al 2009). A bioactive, degradable, and cytocompatible akermanite $\left(\mathrm{Ca}_{2} \mathrm{MgSi}_{2} \mathrm{O}_{7}\right)$ scaffold with high porosity $(63.5-90.3 \%)$ and pore interconnectivity with a corresponding compressive strength between 1130 and $530 \mathrm{kPa}$ has been reported (Wu et al 2005). Akermanite and wollastonite have also been studied for drug delivery (Dora et al 2008).

\footnotetext{
*Author for correspondence (bhatkar_vinod@yahoo.com)
}

Most of the silicates have high melting points. Moreover, they can appear in crystalline as well as glassy form. Synthesis of silicates is rather tricky for these reasons. Conventionally, solid-state diffusion methods have been used for the synthesis of silicates. Akermanite ceramics prepared by sintering akermanite powder compacts at $1370^{\circ} \mathrm{C}$ for $6 \mathrm{~h}$, is previously reported ( $\mathrm{Wu}$ and Chang 2006). Pure akermanite $\left(\mathrm{Ca}_{2} \mathrm{MgSi}_{2} \mathrm{O}_{7}\right)$ powders with polycrystalline particles having dimensions of 5-40 $\mu \mathrm{m}$ were synthesized by sol-gel method (Wu and Chang 2004). The combustion synthesis as a preparation process to produce homogeneous, very fine crystalline, unagglomerated, multicomponent oxide ceramic powders without the intermediate decomposition and/or calcining steps has attracted a good deal of attention (Kingsley and Patil 1988; Kingsley et al 1990). The combustion synthesis is based on the exothermic reaction between fuel and oxidizer. The combustion process has several advantages over the other methods in terms of simplicity, costeffectiveness, energy saving, purity and homogeneity. The combustion-derived powders have narrow size distribution with average agglomerate particle sizes in the range of $0.5-$ $5 \mu \mathrm{m}$. The fine particle nature of the combustion-derived powder is attributed to the low exothermicity of the combustion reaction and evolution of large amount of gases $\left(\mathrm{NH}_{3}\right.$, $\mathrm{H}_{2} \mathrm{O}, \mathrm{CO}_{2}$ ), which help to dissipate the heat thereby preventing the oxides from sintering (Ekambaram and Patil 1995, 1997; Chandrappa et al 1999).

The luminescence properties of biomaterials may be useful in studying osteoblast adhesion and proliferation, host-biomaterial interaction, to observe the in vivo course biomaterial-associated infections. This luminescent material may be potentially applied in the drug delivery and disease therapy fields. 


\section{Experimental}

In this study $\left(\mathrm{Ca}_{2-x} \mathrm{Sr}_{x}\right) \mathrm{MgSi}_{2} \mathrm{O}_{7}: \mathrm{Eu}^{3+}$ with $x$-values 0 , $0.5,1.5$ and 2 were synthesized by combustion method. The detailed description of the methods can be found in the original works of Patil and co-workers (Kingsley and Patil 1988; Kingsley et al 1990; Suresh et al 1991; Manoharan and Patil 1992; Ravindranathan et al 1993; Ekambaram and Patil 1995, 1997). Ingredients used were metal carbonates, silicic acid $\left(\mathrm{SiO}_{2} \cdot x \mathrm{H}_{2} \mathrm{O}\right)$ and dopant salts. The dopant europium concentration was 2 mol \% of alkaline earth ion. An equivalent amount of $\mathrm{Eu}_{2} \mathrm{O}_{3}$ was dissolved in $3 \mathrm{M}$ nitric acid for this purpose. Urea was used as a fuel and ammonium nitrate as oxidizer. Fuel to oxidizer ratio, optimized as described by Bhatkar et al $(2002,2007)$ was used. Details of the molar ratio of ingredients used in the synthesis of all compounds are given in table 1 .

All constituents in stoichiometric proportions, along with fuel and oxidizer were mixed together and small quantity of double distilled water was added. The mixture on thoroughly mixing was transferred to a pre-heated furnace at $500^{\circ} \mathrm{C}$. On rapid heating the mixture evaporated and ignited at $450^{\circ} \mathrm{C}$, with the evolution of a large amount of gases, to yield silicates. Entire process was completed within a few minutes. The as-prepared phosphors did not show intense emission, probably the activator $\mathrm{Eu}$ was not incorporated in divalent form. The phosphors were reheated, in the reducing atmosphere provided by heating in a closed box with charcoal, at $900^{\circ} \mathrm{C}$ for $1 \mathrm{~h}$.

Photoluminescence (PL) spectra were recorded on a Hitachi F-4000 spectro-fluorimeter with a spectral slit width of $1.5 \mathrm{~nm}$, at room temperature. To confirm the structure of the synthesized phosphors, powder photographs were obtained using Philips diffractometer, PW 1710.

\section{Results and discussion}

Akermanite belongs to the tetragonal crystal system with space group, $P 42_{1} m$, where $a=7 \cdot 8288, c=5 \cdot 0052, Z=2$ and point group $42 \mathrm{~m}$. It is optically transparent to translucent and colourless. The X-ray powder pattern is characterized by strong lines at 2.87 (100), 3.09 (30), 1.764 (30), 2.039 (20), 2.488 (18), 3.73 (14), 5.55 (12) (Swainson et al 1992). Both $\mathrm{Ca}_{2} \mathrm{MgSi}_{2} \mathrm{O}_{7}$ and $\mathrm{Sr}_{2} \mathrm{MgSi}_{2} \mathrm{O}_{7}$ have akermanite structure. In this type of structure there is one calcium or strontium site, which is coordinated by eight oxygen ions. The review of the data from the earlier studies (Blasse et al 1968; Poort et al 1997) on the nature of emission and the decay time for these phosphors and comparison with the results from this study, are summarized in table 2.

The PL properties of individual compounds are discussed below: Figure 1 shows the excitation spectra

Table 1. Details of molar ratio of ingredients used in synthesis.

\begin{tabular}{|c|c|c|c|c|c|c|}
\hline \multirow{3}{*}{$\frac{\text { Sl. no. }}{1}$} & \multicolumn{2}{|c|}{ Name of compound } & \multicolumn{4}{|c|}{ Starting materials } \\
\hline & $\mathrm{Ca}_{2} \mathrm{MgSi}_{2} \mathrm{O}_{7}: \mathrm{Eu}^{2+}$ & $\mathrm{CaCO}_{3}, \mathrm{Mg}\left(\mathrm{NO}_{3}\right)_{2}$ & $\mathrm{SiO}_{2} \cdot x \mathrm{H}_{2} \mathrm{O}$ & $\mathrm{Eu}\left(\mathrm{NO}_{3}\right)_{2}$ & $\mathrm{NH}_{4} \mathrm{NO}_{3}$ & Urea \\
\hline & Mole ratio:-> & $1 \cdot 96,1$ & 2 & 0.04 & 30 & 35 \\
\hline \multirow[t]{2}{*}{2} & $\mathrm{Ca}_{1.5} \mathrm{Sr}_{0.5} \mathrm{MgSi}_{2} \mathrm{O}_{7}: \mathrm{Eu}^{2+}$ & $\mathrm{CaCO}_{3}, \mathrm{SrCO}_{3}, \mathrm{Mg}\left(\mathrm{NO}_{3}\right)_{2}$ & $\mathrm{SiO}_{2} \cdot x \mathrm{H}_{2} \mathrm{O}$ & $\mathrm{Eu}\left(\mathrm{NO}_{3}\right)_{2}$ & $\mathrm{NH}_{4} \mathrm{NO}_{3}$ & Urea \\
\hline & Mole ratio:- > & $1 \cdot 46,0 \cdot 5,1$ & 2 & $0 \cdot 04$ & 30 & 35 \\
\hline \multirow[t]{2}{*}{3} & $\mathrm{Ca}_{0.5} \mathrm{Sr}_{1.5} \mathrm{MgSi}_{2} \mathrm{O}_{7}: \mathrm{Eu}^{2+}$ & $\mathrm{CaCO}_{3}, \mathrm{SrCO}_{3}, \mathrm{Mg}\left(\mathrm{NO}_{3}\right)_{2}$ & $\mathrm{SiO}_{2} \cdot x \mathrm{H}_{2} \mathrm{O}$ & $\mathrm{Eu}\left(\mathrm{NO}_{3}\right)_{2}$ & $\mathrm{NH}_{4} \mathrm{NO}_{3}$ & Urea \\
\hline & Mole ratio:- > & $0 \cdot 5,1 \cdot 46,1$ & 2 & 0.04 & 30 & 35 \\
\hline \multirow[t]{2}{*}{4} & $\mathrm{Sr}_{2} \mathrm{MgSi}_{2} \mathrm{O}_{7}: \mathrm{Eu}^{2+}$ & $\mathrm{SrCO}_{3}, \mathrm{Mg}\left(\mathrm{NO}_{3}\right)_{2}$ & $\mathrm{SiO}_{2} \cdot x \mathrm{H}_{2} \mathrm{O}$ & $\mathrm{Eu}\left(\mathrm{NO}_{3}\right)_{2}$ & $\mathrm{NH}_{4} \mathrm{NO}_{3}$ & Urea \\
\hline & Mole ratio:- > & $1 \cdot 96,1$ & 2 & $0 \cdot 04$ & 30 & 35 \\
\hline
\end{tabular}

Table 2. Review of data from earlier studies and comparison with results from this study on nature of emission and decay time.

\begin{tabular}{llcccccc}
\hline Sl. No. & Name of compound & $\begin{array}{c}\text { Crystal } \\
\text { structure }\end{array}$ & $\begin{array}{c}\text { Emission } \\
\text { peak }(\mathrm{nm})\end{array}$ & $\begin{array}{c}\text { Emission } \\
\text { peak }(\mathrm{nm})^{\mathrm{a}}\end{array}$ & $T_{50}(\mathrm{~K})$ & $\begin{array}{c}\text { Decay } \\
\text { time }(\mu \mathrm{s})\end{array}$ & Reference \\
\hline 1 & $\mathrm{Ca}_{2} \mathrm{MgSi}_{2} \mathrm{O}_{7}: \mathrm{Eu}^{2+}$ & Akermanite & 535 & $475 \mathrm{bb}$ & 285 & $0 \cdot 2$ & $\begin{array}{c}\text { Blasse } \text { et al }(1968) \\
\text { Poort } \text { et al }(1997)\end{array}$ \\
& & & 545 & & 280 & $1 \cdot 1$ & Poort et al $(1997)$ \\
3 & $\mathrm{Ca}_{1.5} \mathrm{Sr}_{0.5} \mathrm{MgSi}_{2} \mathrm{O}_{7}: \mathrm{Eu}^{2+}$ & & 525 & 448 & 280 & $1 \cdot 0$ & Poort et al $(1997)$ \\
4 & $\mathrm{Ca}_{0.5} \mathrm{Sr}_{1.5} \mathrm{MgSi}_{2} \mathrm{O}_{7}: \mathrm{Eu}^{2+}$ & & 490 & 450 & 280 & $0 \cdot 8$ & Blasse et al $(1968)$ \\
& $\mathrm{Sr}_{2} \mathrm{MgSi}_{2} \mathrm{O}_{7}: \mathrm{Eu}^{2+}$ & Akermanite & 470 & 457 & 305 & $0 \cdot 3$ & Poort et al (1997) \\
\hline
\end{tabular}

\footnotetext{
${ }^{\mathrm{a}}$ This work for PL measurements at room temperature. ${ }^{\mathrm{b}}$ Literature values at $4.2 \mathrm{~K}$
} 


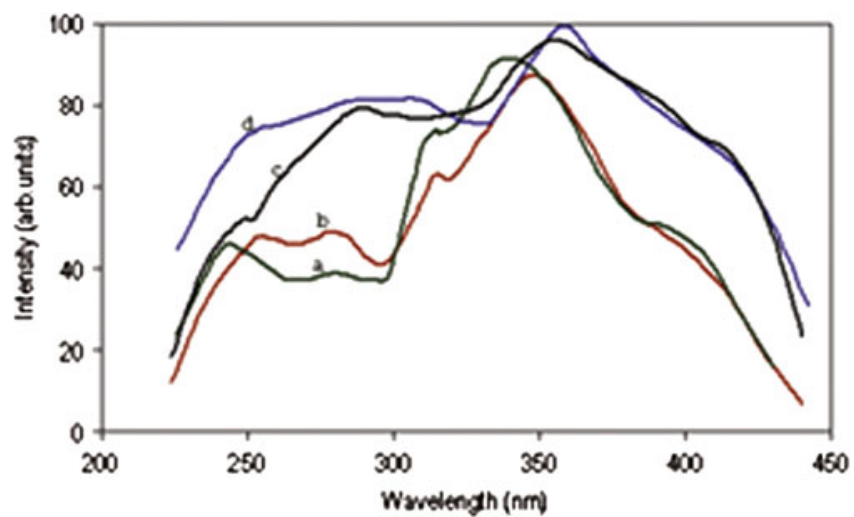

Figure 1. PL spectra for $\mathrm{Eu}^{2+}$ doped disilicate a. $\mathrm{Ca}_{2} \mathrm{MgSi}_{2} \mathrm{O}_{7}$ excitation for $447 \mathrm{~nm}$ emission, b. $\mathrm{Ca}_{1.5} \mathrm{Sr}_{0.5} \mathrm{MgSi}_{2} \mathrm{O}_{7}$ excitation for $448 \mathrm{~nm}$ emission, c. $\mathrm{Ca}_{0.5} \mathrm{Sr}_{1.5} \mathrm{MgSi}_{2} \mathrm{O}_{7}$ excitation for $478 \mathrm{~nm}$ emission and d. $\mathrm{Sr}_{2} \mathrm{MgSi}_{2} \mathrm{O}_{7}$ excitation for $460 \mathrm{~nm}$ emission.

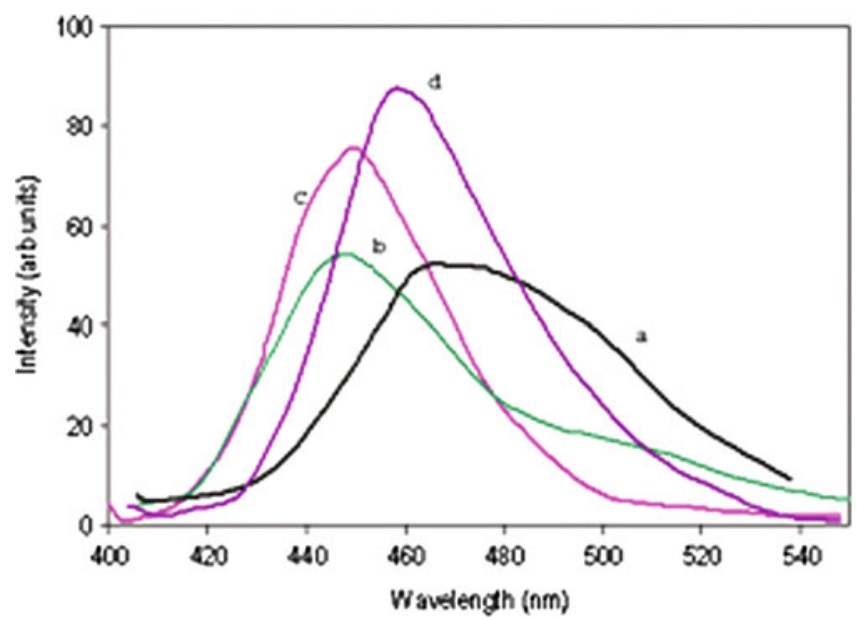

Figure 2. PL spectra for $\mathrm{Eu}^{2+}$ doped disilicate a. $\mathrm{Ca}_{2} \mathrm{MgSi}_{2} \mathrm{O}_{7}$ emission for $385 \mathrm{~nm}$ excitation, b. $\mathrm{Ca}_{1.5} \mathrm{Sr}_{0.5} \mathrm{MgSi}_{2} \mathrm{O}_{7}$ emission for $385 \mathrm{~nm}$ excitation, c. $\mathrm{Ca}_{0.5} \mathrm{Sr}_{1.5} \mathrm{MgSi}_{2} \mathrm{O}_{7}$ emission for $385 \mathrm{~nm}$ excitation and d. $\mathrm{Sr}_{2} \mathrm{MgSi}_{2} \mathrm{O}_{7}$ emission for $385 \mathrm{~nm}$ excitation.

for $\mathrm{Ca}_{2} \mathrm{MgSi}_{2} \mathrm{O}_{7}: \mathrm{Eu}^{2+}, \mathrm{Ca}_{1.5} \mathrm{Sr}_{0.5} \mathrm{MgSi}_{2} \mathrm{O}_{7}: \mathrm{Eu}^{2+}, \mathrm{Ca}_{0.5} \mathrm{Sr}_{1.5}$ $\mathrm{MgSi}_{2} \mathrm{O}_{7}: \mathrm{Eu}^{2+}$, and $\mathrm{Sr}_{2} \mathrm{MgSi}_{2} \mathrm{O}_{7}: \mathrm{Eu}^{2+}$. The emission spectra are shown in figure 2. Efficient excitation by $385 \mathrm{~nm}$ was observed for $\mathrm{Eu}^{2+}$ doped disilicates as seen from figure 1. The emission spectrum of $\mathrm{Ca}_{2} \mathrm{MgSi}_{2} \mathrm{O}_{7}: \mathrm{Eu}^{2+}$ (curve a), is a broad band at $475 \mathrm{~nm} . \mathrm{Ca}_{1.5} \mathrm{Sr}_{0.5} \mathrm{MgSi}_{2} \mathrm{O}_{7}: \mathrm{Eu}^{2+}$ (curve b) exhibits blue emission around $448 \mathrm{~nm}$. Emission in $\mathrm{Ca}_{0.5} \mathrm{Sr}_{1.5} \mathrm{MgSi}_{2} \mathrm{O}_{7}: \mathrm{Eu}^{2+}$ (curve g) peaks at $450 \mathrm{~nm}$. Emission in $\mathrm{Sr}_{2} \mathrm{MgSi}_{2} \mathrm{O}_{7}: \mathrm{Eu}^{2+}$ (curve h) peaks at around $457 \mathrm{~nm}$. Excitation spectrum of all the samples (curves a-d) shows considerable intensity at $385 \mathrm{~nm}$. At room temperature the intensity of emission, except for $\mathrm{Sr}_{2} \mathrm{MgSi}_{2} \mathrm{O}_{7}: \mathrm{Eu}^{2+}$ is considerably quenched, which is consistent with the literature data. The luminescence process of $\mathrm{Eu}^{2+}$-activated phosphor is characterized by the ${ }^{4} f_{6}{ }^{5} d \rightarrow{ }^{4} f_{7}$ transition of $\mathrm{Eu}^{2+}$ acting as an activator centre. The absorption and emission due to

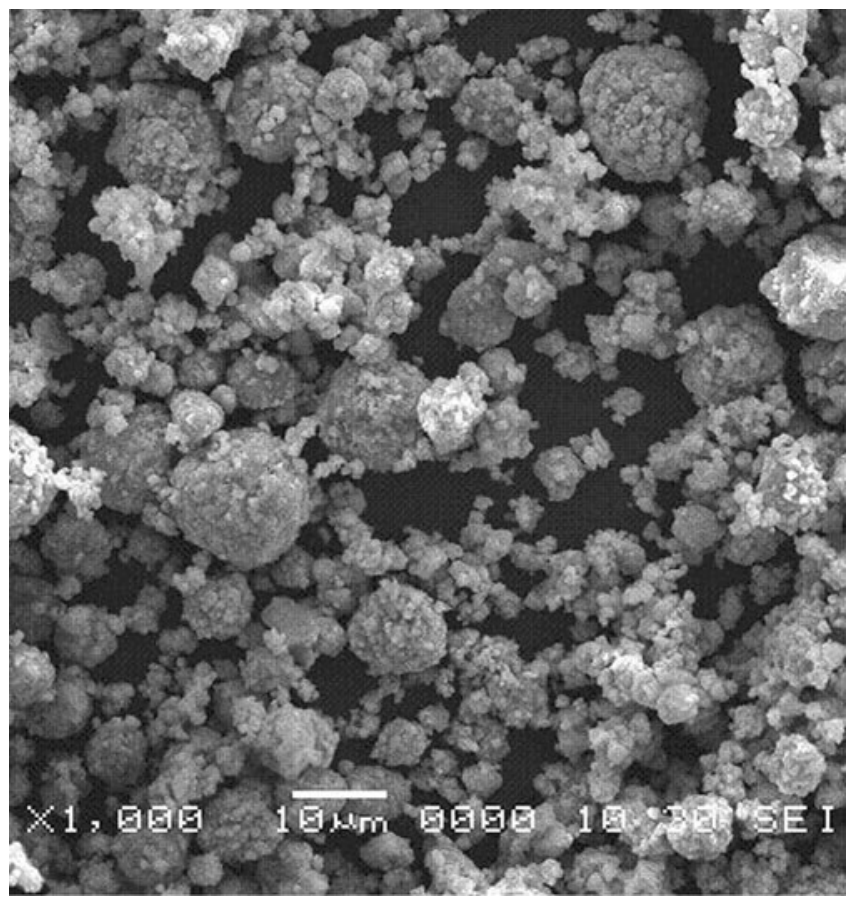

Figure 3. SEM image of combustion synthesized material without calcinations.

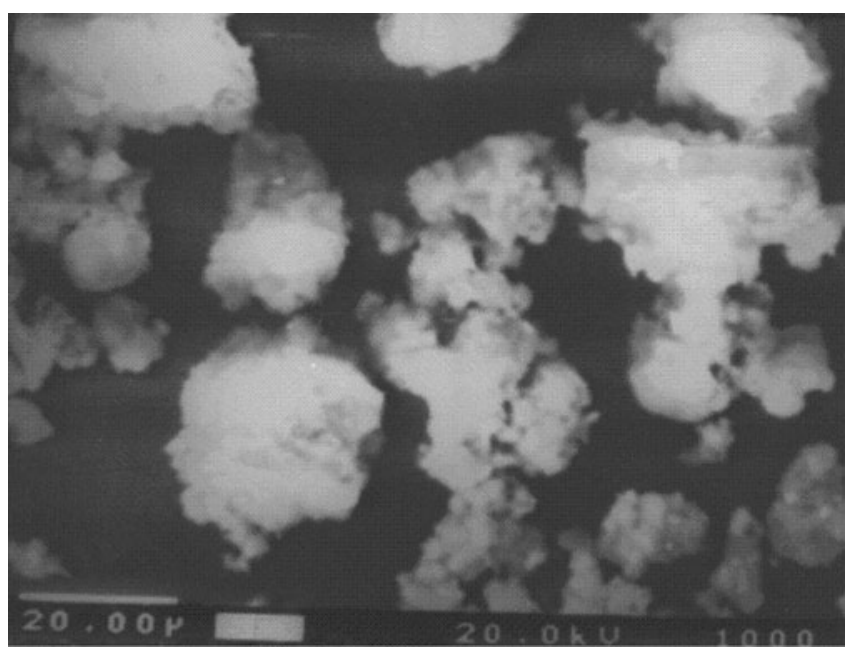

Figure 4. SEM image of combustion synthesized material heated at $900^{\circ} \mathrm{C}$

the transition between ${ }^{4} f_{7}$ and ${ }^{4} f_{6}{ }^{5} d$ states of $\mathrm{Eu}^{2+}$ strongly depend on host material, cations replaceable by $\mathrm{Eu}^{2+}$ in the host matrix and the crystal field acting on $\mathrm{Eu}^{2+}$.

The morphology and size of the prepared materials were determined from SEM studies. Figure 3 shows a typical image of the combustion synthesized material. The precursor powders had spherical-like shape and micron size. It also shows agglomerated grains which might be due to the residence time of the powder inside a combustion furnace. The morphology of the powder heated at a temperature of $900^{\circ} \mathrm{C}$ 
is shown in figure 4. The particles form a cluster and the particle size increases with heating.

\section{Conclusions}

Both $\mathrm{Ca}_{2} \mathrm{MgSi}_{2} \mathrm{O}_{7}: \mathrm{Eu}^{2+}$ and $\mathrm{Sr}_{2} \mathrm{MgSi}_{2} \mathrm{O}_{7}: \mathrm{Eu}^{2+}$ have akermanite structures. The combustion synthesis using urea and ammonium nitrate is an easy, time saving and cost effective method for the synthesis. The photoluminescence study of these materials show the strong emission of $\mathrm{Eu}^{2+}$ in alkaline earth silicates which agrees well with the literature. The biocompatibility of the akermanite has already been reported by many researchers. The luminescence properties of these biomaterials may be useful in their use as biomarkers and in the controlled drug delivery.

\section{References}

Bhatkar V B, Omanwar S K and Moharil S V 2002 Phys. Status Solidi (a) 191272

Bhatkar V B, Omanwar S K and Moharil S V 2007 Opt. Mater. 29 1066

Blasse G et al 1968 Philips Res. Rep. 23189

Cerruti M and Sahai N 2006 Rev. Mineral. Geochem. 64283

Chandrappa G T, Ghosh S and Patil K C 1999 J. Mater. Synth. Process. 7273

Dora A, Hernández C, Luis A, Aragón B, Lara W O, RenteríaZamarrón D and Salinas-Delgado Y 2008 Bioceramics 21527

Ekambaram S and Patil K C 1995 Bull. Mater. Sci. 18921

Ekambaram S and Patil K C 1997 J. Alloys Compd 2487

Hench L L 1991 J. Am. Ceram. Soc. 741487

Hench L L 1998 Biomaterials 191419

Hongli S et al 2006 Biomaterials 275651

Huang Y et al 2009 Biomaterials 305041
Iwata N Y, Lee G H, Tokuoka Y and Kawashima N 2004 Colloids Surf. B Biointerf. 34239

Kingsley J J and Patil K C 1988 Mater. Lett. 6427

Kingsley J J, Manickam N and Patil K C 1990 Bull. Mater. Sci. 13 179

Liu Q, Cen L, Yin S, Chen L, Liu G, Chang J and Cui L 2008 Biomaterials 294792

Liu X, Ding C and Chu P K 2004 Biomaterials 251755

Manoharan S S and Patil K C 1992 J. Am. Ceram. Soc. 751012

Nonami T and Tsutsumi S 1999 J. Mater. Sci. Mater. Med. 10 475

Ou J, Kang Y, Huang Z, Chen X, Wu J, Xiao R and Yin G 2008 Biomed. Mater. 38

Poort S M H, Meyerink A and Blasse G 1997 J. Phys. Chem. Solids 581451

Radev L, Hristov V, Michailova I and Samuneva B 2009 Central Eur. J. Chem. 7322

Ravindranathan P, Komarneni S and Roy R 1993 J. Mater. Sc. Lett. 12369

Suresh K, Kumar N R S and Patil K C 1991 Adv. Mater. 3148

Swainson I P, Dove M T, Schmahl W S and Putnis A 1992 Phys. Chem. Miner. 19185

Wu C and Chang J 2004 Mater. Lett. 582415

Wu C and Chang J 2006 J. Biomater. Appl. 21119

Wu C and Chang J 2007 J. Biomed. Mater. Res. B Appl. Biomater. 83153

Wu C, Chang J, Zhai W, Ni S and Wang J 2005 J. Biomed. Mater. Res. B78 47

Wu C, Chang J, Ni S and Wang J 2006 J. Biomed. Mater. Res. A76 73

Wu C, Ramaswamy Y, Kwik D and Zreiqat H 2007 Biomaterials 28 3171

Xu S et al 2008 Biomaterials 292588

Xue M, Ou J, Zhou D L, Feng D, Yang W Z, Li G, Liu D P and Wang Y S 2007 Key Eng. Mater.: Bioceram. 19169

Yan H, Xiaogang J, Xiaoling Z, Hongli S, Jinwen T, Tingting T, Jiang C and Kerong D 2009 Biomaterials 305041 